\title{
Putusan Hakim Anak Perempuan Mahjub Saudara Pewaris Dalam Pewarisan di Pengadilan Agama Lombok Barat Beserta Implikasinya
}

\author{
Kaswadi \\ Program Studi Magister Hukum Keluarga Islam, Universitas Islam Negeri Mataram
}

dikirim:2 Agustus 2021

direvisi:23 Desember 2021

diterima: 27 Desember 2021

\begin{abstract}
Abstrak:
Perkembangan hukum kewarisan di Indonesia dewasa ini mengalami kemajuan yang cukup penting bagi kedudukan ahli waris anak perempuan di dalam menerima harta warisan. Telah terjadi pembaharuan hukum dalam yurisprudensi dimana anak perempuan dapat menghijab (penghalang) bagi ahli waris lainnya seperti saudara pewaris dalam menerima warisan. Tujuan penelitian ini adalah untuk mengetahui faktor-faktor yang mempengaruhi pertimbangan Hakim dalam menjatuhkan putusan serta untuk menganalisis implikasi sosial dan hukum putusan tersebut terhadap perkembangan kewarisan anak perempuan di Kabupaten Lombok Barat. Penelitian ini merupakan penelitian kualitatif yang dilakukan melalui pendekatan yuridis empiris dengan fokus analisis adalah putusan Nomor: 296/Pdt.G/2019/PA.GM, tanggal 10 Nopember 2020 sebagai data primer disamping hasil wawancara dari hakim yang memutus dan data sekunder diperoleh dari bahan kepustakaan. Penggalian dan pengumpulan data dalam penelitian ini dilakukan dengan tehnik observasi, wawancara mendalam dan studi dokumentasi dengan analisis data menggunakan analisis data kualitatif. Hasil penelitian menunjukkan bahwa Hakim Pengadilan Agama Lombok Barat dalam putusan perkara tersebut mengikuti pembaharuan hukum sebagaimana yurisprudensi (Putusaan MA. RI, No. 86 K/AG/1994), yaitu tidak memberikan bagian waris kepada saudara pewaris (paman/bibi) karena terhijab oleh keberadaan ahli waris anak perempuan dan faktor yang mempengaruhi pertimbangan hakim dalam putusan tersebut adalah rasa keadilan dan yurisprudensi. Putusan tersebut memiliki implikasi sosial dan hukum terhadap perkembangan kewarisan anak perempuan di Kabupaten Lombok Barat.
\end{abstract}

Kata kunci: Anak perempuan, Mahjub, Pembagian Waris, Putusan Pengadilan, Implikasi Putusan.

\section{Abstract:}

The development of inheritance law in Indonesia today has progressed, which is essential for female heirs' position in receiving the inheritance. There has been a legal reform in jurisprudence where girls can wear the hijab (barrier) for other heirs such as the heir's siblings in receiving the inheritance. The purpose of this study was to determine the factors that influence the judge's consideration in making a decision and to analyze the social and legal implications of the decision on the development of inheritance for girls in the West Lombok Regency. This qualitative research is conducted through an empirical juridical approach with the focus of analysis being the decision Number: 296/Pdt.G/2019/PA.GM, November 10, 2020, as primary data in addition to the results of interviews from judges who decide and secondary data obtained from material literature. Excavation and data collection in this study was carried out using observation techniques, in-depth interviews, and documentation studies with data analysis using qualitative data analysis. The results showed that the judges of the West Lombok Religious Court in the decision of the case followed the legal reforms according to jurisprudence (Judgment MA. RI, No. 86 K/AG/1994), which did not give inheritance shares to the heir's siblings (uncle/aunt) because the existence of 
daughter heirs veiled them. The factors that influence the judge's consideration in the decision are a sense of justice and jurisprudence. The decision has social and legal implications for girls' inheritance in the West Lombok Regency.

Keywords: Daughters, Mahjub, Distribution of Inheritance, Court Decisions, Implications of Decisions.

\section{PENDAHULUAN}

Perkembangan hukum kewarisan di Indonesia dewasa ini mengalami kemajuan yang cukup penting bagi kedudukan ahli waris anak perempuan di dalam menerima harta warisan. Telah terjadi pembaharuan hukum dimana anak perempuan dapat menjadi mahjub (penghalang) bagi ahli waris lainnya seperti saudara pewaris dalam menerima warisan dan porsi bagian waris anak perempuan bisa juga sama dengan bagian anak laki-laki. PutusanPutusan kewarisan dalam lingkup peradilan agama terkait pembaharuan hukum tersebut diatas telah menjadi yurisprudensi.

Dalam hukum kewarisan yang menarik untuk dikaji adalah posisi dan kedudukan ahli waris anak perempuan ketika bersama sama dengan saudara pewaris atau paman/bibi di dalam suatu pewarisan. Di Indonesia berlaku tiga sistem hukum kewarisan yaitu kewarisan berdasarkan hukum perdata barat (BW), hukum adat, dan hukum Islam (Muhammad Burhan, 2017). Didalam ketiga sistem hukum kewarisan tersebut, antara hukum kewarisan yang diatur dalam
KUHPerdata (BW), hukum adat dan hukum Islam, memposisikan kedudukan ahli waris anak perempuan ketika bersama sama dengan saudara pewaris (paman/bibi) berbeda-beda.

Dalam KUHPerdata menentukan bahwa anak perempuan bersama dengan anak laki-laki merupakan ahli waris utama dimana sadara pewaris tidak memiliki tempat jika terdapat anak laki-laki maupun anak perempuan dalam suatu pewarisan. Dalam hukum kewarisan adat, menentukan posisi dan kedudukan ahli waris anak perempuan, didasarkan pada adat kebiasaan yang berlaku di masingmasing daerah atau suatu komunitas masyarakat adat berdasarkan pola kekerabatan yang dimiliki. (Muhammad Burhan, 2017). Ada yang menentukan kedudukan dan posisi anak perempuan adalah sama dengan saudara pewaris dan ada pula yang menentukan anak perempuan sebagai penghalang saduara pewaris dalam menerima warisan dari pewaris.

Dalam ketentuan hukum kewarisan Islam menentukan bahwa anak perempuan memiliki kedudukan dan posisi 
yang sama dengan saudara pewaris dalam menerma wrisan dari pewaris, hal ini ditegaskan dalam Al-Qur'an surat An-Nisa 176.

Terkait pembagian waris anak perempuan, dalam tulisan ini penulis akan melakukan pengkajian dan pembahasan terhadap pembagian waris anak perempuan dalam putusan-putusan Peradilan Agama, karena dalam perkembangannya putusan-putusan kewarisan dalam lingkungan Peradilan Agama telah mengalami kemajuan yang cukup penting. Hal ini disebabkan karena beberapa putusan Peradilan Agama mengandung pembaharuan hukum.

Di dalam perkembangan hukum kewarisan Islam di Indonesia terdapat beberapa putusan pembaharuan hukum dalam lingkungan Peradilan Agama yang menyangkut kewarisan anak perempuan salah satunya adalah pembaharuan hukum yang mendudukkan posisi anak perempuan yang sebelumnya sejajar atau setara dengan saudara pewaris yang samasama berhak mewarisi harta peninggalan pewaris sebagaimana ketentuan dalam teks-teks hukum Islam dan fikih, menjadi sebaliknya anak perempuan itu menghijab (mahjub) saudara dalam menerima warisan sehingga kemudian melahirkan kaedah hukum, "Anak kandung baik laki-laki maupun perempuan menutup atau menghijab hak waris dari orang-orang yang masih mempunyai hubungan darah dengan pewaris, kecuali orang tua, suami dan istri."

Jika saudara pewaris berama-sama dengan anak perempuan dalam suatu kewarisan, maka saudara pewaris tidak berhak mendapatkan bagian warisan yang ditinggalkan pewaris.. Hal ini diputuskan oleh Mahkamah Agung RI sebagai yurisprudensi dalam Putusan Nomor : 86 K/AG/1994, tanggal 27 Juli 1995, Putusan Mahkamah Agung Republik Indonesia Nomor: 184 K/AG/1995 tanggal 30 September 1996 dan Putusan Mahkamah Agung RI Nomor : 327 K/AG/1997 tanggal 26 Februari 1998,

Disamping itu terdapat pula putusan pembaharuan hukum yang memposisikan anak perempuan memiliki hak yang sama dengan anak laki-laki dalam menerima harta peninggalan pewaris dengan memberikan porsi bagian warisan yang sama rata antara anak lak-laki dengan anak perempuan sebagaimana diputuskan dalam putusan Pengadilan Agama Medan Nomor 92/Pdt.G/2009/PA-Mdn.

Putusan pembaharuan hukum kewarisan lainnya adalah memberikan bagian warisan kepada istri non muslim terhadap harta peninggalan dari suaminya yang muslim. Hal ini tentunya bertentangan dengan khasanah fikih klasik 
yang menyebutkan bahwa salah satu penyebab terputusnya hak mewaris seseorang adalah ketika orang tersebut dalam kondisi non muslim (kafir) atau dalam keadaan murtad. Adanya pendapat bahwa perbedaan agama antara pewaris dengan ahli waris adalah menjadi salah satu penyebab terputusnya hak waris seseorang. mendapatkan gugatan dari para pemikir kontemporer karena dianggap bertentangan dengan nilai universal Islam, keadilan dan hak asasi manusia.

Pemberian bagian warisan kepada istri non muslim terhadap harta peninggalan dari suaminya yang muslim diputuskan oleh Pengadilan Agama Makassar dalam Putusan Nomor : 732/Pdt.G/2008/PA.Mksr, $\quad$ Putusan Pengadilan Tinggi Agama Makassar Nomor : 59/Pdt.G/2009/PTA.Mksr dan Putusan Mahkamah Agung Repulik Indonesia Nomor : 16 K/AG/2010.

Putusan-Putusan pembaharuan sebagaimana diuraikan diatas sudah menjadi yurisprudensi dan sudah sepatutnya di ikuti oleh lembaga peradilan dalam lingkup Peradilan Agama. di dalam menjatuhkan putusan terhadap perkara yang sama.

Namun yurisprudensi merupakan suatu pedoman yang tidak wajib untuk di ikuti oleh para hakim dalam memutus perkara karena itu maka di dalam praktek peradilan, yurisprudensi bisa saja disimpangi atau tidak di ikuti sehingga banyak Pengadilan Agama dalam menjatuhkan putusan mengikuti dan merujuk yurisprudensi tersaebut diatas, akan tetapi banyak juga Pengadilan Agama yang tidak mengikuti atau merujuk yurisprudensi tersebut.

Pengkajian terhadap putusan Pengadilan Agama Lombok Barat terkait dengan putusan kewarisan anak perempuan ketika bersama sama dengan saudra pewaris dalam suatu pewarisan menarik untuk dilakukan karena putusan pengadilan agama Lombok Barat tersebut mengandung pembaharuan hukum mengikuti yurisprudensi, yaitu mendudukkan anak perempuan sebagai penghijab saudara pewaris jika bersamasama dalam suatu pewarisan yaitu tidak memberikan bagaian waris kepada saudara pewaris (paman/bibi) jika bersama anak perempuan dalam suatu pewarisan.

Putusan Pengadilan Agama Lombok Barat tersebut memiliki implikasi atau dampak sosial dan hukum yang cukup penting bagi perkembangan kewarisan anak perempuan di Kabupaten Lombok Barat.

Rumusan masalah yang dapat diangkat sebagai pedoman dalam melakukan penelitian ini adalah faktorfaktor apakah yang mempengaruhi dan 
menjadi dasar pertimbangan hukum hakim Pengadilan Agama di Lombok Barat dalam menjatuhkan putusan anak perempuan mahjub atau tidak mahjub saudara pewaris? dan bagaimana implikasi sosial dan hukum dari putusanputusan tersebut terhadap perkembangan kewarisan anak perempuan di Kabupaten Lombok Barat?.

Terkait tema yang diangkat dalam tulisan ini yang berkaitan dengan kwewarisan anak perempuan perspektif putusan Pengadilan Agama telah banyak ditulis dan dilakukan penelitian oleh penulis atau peneliti terdahulu. Untuk memperbandingkan penelitian yang dilakukan penulis dengan penelitianpenelitian atau penulisan sebelumnya, penulis memaparkan beberapa tulisan atau penelitian yang telah dilakukan berbagai pihak berkaitan dengan posisi dan kedudukan ahli waris anak perempuan dalam kajian putusan Pengadilan Agama di Indonesia.

Tulisan dari Baiq Tria Arinda Erlyta dengan Judul "Analisis terhadap Putusan Pengadilan Agama Praya Nomor 0038/Pdt.G/2018/Pa.Pra tentang

Pembagian Warisan terhadap Ahli Waris Perempuan”. Baiq Tria Arinda Erlyta memfokuskan penelitiannya pada konsep dan pengaturan pembagian waris menurut Kompilasi Hukum Islam (KHI) dan hukum adat terkait keberadaan janda, anak perempuan dan anak laki-laki dalam suatu kewarisan dengan melakukan studi terhadap putusan Pengadilan Agama Praya khusus terhadap perkara nomor: 038/Pdt.G/2018/PA.Pra. Bagaimana dasar pertimbangan hakim dalam putusan tersebut. Penelitian yang digunakan adalah penelitian hukum normatif dengan pendekatan kualitatif (Baiq Tria Arinda Erlyta, 2019).

Tesis Mohammad Amron dengan judul "Kedudukan Ahli Waris Anak Perempuan bersama Ahli Waris Saudara dalam Hukum Waris Islam di Pengadilan Agama Semarang”. Mohammad Amron memfokuskan penelitiannya terhadap keberadaan dan posisi ahli waris anak perempuan bersama ahli waris saudara ayah (paman/bibi) dalam suatu kewarisan dengan melakukan kajian terhadap putusan Peradilan Agama Semarang. Penelitian ini dilaksanakan di Pengadilan Agama Semarang dengan menggunakan metode pendekatan yuridis normatif. Data-data diperoleh melalui kepustakaan dan dilengkapi dengan hasil wawancara, data yang diperoleh kemudian dianalisis secara kualitatif. Dari hasil peneiltian menunjukkan bahwa Hakim Pengadilan Agama Semarang memberikan kedudukan bagi anak perempuan sama atau setara dengan anak laki-laki dalam menghijab 
atau menghalangi saudara pewaris (paman/bibi) dalam pelaksanaan pembagian warisan. (Mohammad Amron, 2016).

Tulisan dari Emy Eliamega Saragih, Mustamam, Mukidi berjudul "Kedudukan Anak Perempuan dalam Pembagian Harta Warisan Menurut Hukum Islam (Studi Kasus Putusan Pengadilan Agama Medan No. 40/Pdt.G/2017/PA.Mdn)." Emy Eliamega Saragih, Mustamam, Mukidi memfokuskan penelitiannya terhadap putusan Pengadilan Agama Medan No. 40/Pdt.G/2017/PA.Mdn. untuk mengetahui bagaimana posisi anak perempuan dalam distribusi hukum waris Islam, hak waris saudara kandung dari ayah yang meninggalkan anak perempuan dalam perspektif hukum Islam. Penelitian dilakukan melalui pendekatan yuridis normatif dengan pendekatan kasus dan menganalisis Putusan No. 40 / Pdt.G / 2017 / PA. Mdn). sumber data sekunder diperoleh dari hasil penelitian kepustakaan. Analisis data yang digunakan adalah analisis data kualitatif. Dalam tulisannya Emy Eliamega Saragih, Mustamam, Mukidi menyatakan berdasarkan hasil penelitian, bahwa posisi anak perempuan dalam distribusi hukum waris menurut Islam sama dengan posisi anak laki-laki, yaitu keduanya memiliki hak untuk mewarisi warisan orang tua atau saudara mereka. Hanya saja, porsi laki-laki lebih besar daripada bagian perempuan, yaitu bagian anak laki-laki adalah dua bagian anak perempuan sedangkan hakhak waris saudara kandung ayah yang meninggalkan anak perempuan dalam perspektif hukum Islam didasarkan pada bi ghairihi asabah, karena mereka mewarisi dari lelaki dan perempuan secara bersama-sama. Dasar pertimbangan Hakim Pengadilan Agama Medan dalam penentuan ahli waris dalam putusan Nomor: 40/ Pdt.G/2017/PA.Mdn, adalah Pasal 174 ayat (2) Kompilasi Hukum Islam dan Al-Quran surat An-Nisa ayat 176 (Emy Eliamega Saragih, Mustamam, Mukidi, 2019)

Tulisan Azka Anwar, Syamsul Bahri berjudul "Studi Kasus Putusan Nomor 92/Pdt.G/2009/PA-Mdn. tentang Pembagian Warisan Sama Rata Anak Laki-Laki dan Anak Perempuan." Azka Anwar, Syamsul Bahri melakukan penelitian terhadap kedudukan anak perempuan dalam keadaan jika bersmasama dengan anak laki-laki dalam suatu pembagian warisan dengan melakukan kajian terhadap putusan Pengadilan Agama Medan nomor: 92/Pdt.G/2009/PAMdn. Hasil penelitiannya Azka Anwar, Syamsul Bahri menemukan adanya pembaharuan hukum yang dilakukan oleh 
Pengadilan Agama Medan dalam putusan Nomor : 92/Pdt.G/2009/PA-Mdn tersebut. Hakim Pengadilan Agama Medan tidak menerapkan ketentuan pasal $176 \mathrm{KHI}$ yang menentukan bahwa bagian anak lakilaki adalah dua berbanding satu dengan anak perempuan. Hakim Pengadilan Agama Medan mendudukkan anak perempuan memiliki hak yang sama dengan anak laki-laki sehingga memberikan bagian yang sama dengan anak laki-laki. Penerapan hukum yang dilakukan dalam putusan tersebut menyatakan bahwa anak laki-laki dan anak perempuan mendapatkan bagian yang sama rata. Putusan ini diterima oleh kedua belah pihak dilihat dari tidak adanya upaya hukum yang dilakukan oleh kedua belah pihak. Penelitian ini merupakan penelitian yuridis normatif melalui penelitian kepustakaan dengan menggunakan pendekatan metode kualitatif (Azka Anwar dan Syamsul Bahri, 2017).

Tulisan Rochmad dengan judul "Pembagian Harta Waris antara Anak Laki-Laki dan Anak Perempuan : Studi Putusan Pengadilan Agama Semarang Nomor: 1545/PDT.G/2010/PA.SM."

Penelitian ini difokuskan pada pembagian waris anak perempuan dan anak laki-laki dengan melakukan kajian terhadap Putusan Pengadilan Agama Semarang Nomor: 1545/PDT.G/2010/PA.SM. Pada putusan tersebut Pengadilan Agama Semarang memberikan bagian waris anak perempuan adalah separoh dari bagian anak laki-laki sebagaimana yang ditentukan dalam pasal 176 Kompilasi Hukum Islam. Dasar pertimbangan Putusan Hakim Pengadilan Agama Semarang dalam menentukan pembagian harta waris antara anak laki-laki dan anak perempuan, semata-mata lebih didasarkan pada ketentuan teks hukum yang ada, tanpa memberikan argumentasi dan alasan-alasan yang jelas dan tegas, kenapa bagian waris yang diterima oleh anak lakilaki porsinya lebih banyak dari anak perempuan. Penelitian ini merupakan penelitian hukum normatif (Rochmad, 2017).

Berdasarkan beberapa tulisan atau penelitian yang diuraikan diatas, terdapat perbedaan dengan penelitian dan pembahasan yang dilakukan penulis. Meskipun sama-sama meneliti terkait posisi dan kedudukan pembagian waris anak perempuan dalam studi atau tinjauan putusan Peradilan Agama, akan tetapi memiliki perbedaan dengan penelitian yang dilakukan oleh penulis baik dalam hal cakupan masalah yang diteliti, tempat atau lokasi penelitian, putusan-putusan yang menjadi obyek penelitian, maupun yang menyangkut metode dan pendekatan yang digunakan dalam penelitian serta 
mengenai substansi atau materi yang diteliti. Penelitian yang dilakukan penulis adalah difokuskan pada faktor-faktor yang mempengaruhi pertimbangan hakim dalam memutuskan ahli waris anak perempuan mahjub saudara ayah/pewaris dalam suatu pewarisan.

Dibandingkan dengan tulisan atau penelitian sebelumnya, dalam Tulisan atau penelitian ini terdapat suatu kebaruan yaitu dimana peneliti melakukan penelitian yang kemudian menganalisis terkait implikasi hukum dan sosial dari putusan Pengadilan Agama Lombok Barat yang mendudukkan anak perempuan mahjub saudara ayah/pewaris terhadap perkembangan kewarisan anak perempuan di Kabupaten Lombok Barat.

Dalam melakukan analisis terhadap hasil penelitian ini, penulis menggunakan teori perubahan sosial dan hukum dan teori pembaharuan hukum Islam. Perubahan sosial dalam masyarakat dapat membawa implikasi terjadinya perubahan dan pembaruan dalam berbagai bidang, termasuk di dalamnya adalah bidang hukum dan perundang-undangan yang merupakan aspek penting dalam kehidupan manusia. (Syamsuddin Pasamai, 2013).

Sedangkan yang dimaksud dengan perubahan atau pembaharuan hukum adalah perubahan atau pembaharuan dari teks hukum yang ada, perubahan dari peraturan perundang-undangan atau perubahan isi ketentuan-ketentuan dari suatu peraturan perundang-undangan dan perubahan hukum dapat pula terjadi karena adanya perubahan nilai atau kebiasaankebiasaan yang sebelumnya hidup di tengah-tengah masyarakat. (Soerjono Sukanto, 2009).

Secara sosiologis, menurut Satjipto Rahardjo perubahan sosial merupakan ciri yang melekat dalam masyarakat dan hal ini disebabkan karena masyarakat itu mengalami suatu perkembangan. (Artijo Alkostar, M Sholeh Amin, 1986). Oleh karena itu perkembangan tersebut perlu direspon juga oleh hukum Islam, yang pada gilirannya hukum Islam diharapkan mempunyai kemampuan sebagai fungsi social engineering atau sebagai social control yang berfungsi untuk membentuk perilaku sosial.

Hukum Islam sebagai produk kerja intelektual, sering dipahami hanya sebatas pada fikih sehingga sering melahirkan persepsi yang keliru dalam memandang perkembangan atau perubahan yang terjadi dalam hukum Islam.

Dalam pembaharuan hukum islam terdapat satu kaidah yang menyatakan "Muhafadzah 'ala al-qadim al-shalih wa al-akhdzu 'ala al-jadid al-ashlah" artinya : memelihara yang lama jika hal itu masih 
baik dan menerima yang baru atau perubahan jika hal itu dianggap lebih baik. (A. Intan Cahyani, 2016). Di dalam teorinya, Al-Jauziyah menyatakan, "Perubahan ide-ide atau pemikiran hukum dan perbedaannya adalah sesuai dengan perubahan zaman, ruang, keadaan, niat dan kebutuhan". Dan dalam teori lainnya dikatakan "bahwa tidak memahami atau mempertimbangkan perubahan, merupakan kesalahan besar dalam syari'at”. (Rahmat Jatnika, 1996).

Dalam penelitian ini, metode penelitian yang digunakan adalah penelitian kualitatif yaitu penelitian yang bersifat deskriptif dan cenderung menggunakan analisis dengan tujuan agar focus penelitian sesuai dengan fakta-fakta di lapangan. Pendekatan yang digunakan adalah pendekatan yuridis empiris yaitu suatu penelitian disamping melihat aspek hukum positif juga melihat bagaimana penerapannya di masyarakat melalui putusan Peradilan Agama (J. Lexy Meleong, 2005). Bagaimana penerapan norma-norma hukum dalam putusan yang dikeluarkan Pengadilan Agama Lombok Barat terkait perkara kewarisan anak perempuan dan bagaimana implikasi putusan terhadap perkembangan kewarisan anak perempuan di Kabupaten Lombok Barat.
Sumber data yang digunakan dalam penelitian ini adalah Sumber data primer yaitu sumber data yang langsung diperoleh dari lapangan atau obyek penelitian seperti Putusan Pengadilan Agama Lombok Barat Nomor : 296/Pdt.G/2019/PA.GM, tanggal 10 Nopember 2020 dan hasil wawancara/interview dengan Hakim Pengadilan Agama Lombok Barat yang menangani dan memutus perkara tersebut sedangkan sumber data sekunder merupakan sumber data yang diperoleh dari kepustakaan yang meliputi Bahan hukum primair seperti Undang-Undang Nomor 7 Tahun 1989 sebagaimana diubah dengan UU No. 50 Tahun 2009 tentang Peradilan Agama, Undnag-Undang Nomor 48 Tahun 2009 tentang Kekuasaan Kehakimman, Instruksi Presiden Nomor : 1 Tahun 1991 tentang Kompilasi Hukum Islam, Al-Quran dan hadits Nabi. Bahan hukum sekunder seperti yang terdapat di dalam Buku-Buku hukum kewarisan, Artikel-Artikel jurnal ilmiah yang berkaitan dengan kewarisan, Tulisantulisan dalam internet dan Disertasi atau tesis yang berkaitan dengan pembagian waris anak perempuan tinjauan putusan Pengadilan Agama.

Teknik pengumpulan data dalam penelitian ini dilakukan melalui beberapa metode yakni : observasi, dokumentasi dan wawancara (Haris herdiansyah, 2010). 
Observasi yaitu suatu sistem penelitian dengan cara terjun langsung ke lapangan guna untuk melihat secara langsung tentang hal-hal yang akan diteliti (S. Nasution, 2004). Observasi dalam penelitian ini menggunakan jenis observasi non partisipatif. Peneliti melakukan pengamatan, terlebih dahulu dengan cara salah satunya menghadiri persidanganpersidangan dalam perkara kewarisan yang melibatkan ahli waris anak perempuan.

Dokumentasi yaitu salah satu metode pengumpulan data kualitatif yang dilakukan dengan melihat atau menganalisis dokumen yang telah didapatkan berupa arsip Putusan Pengadilan Agama Giri Menang Nomor : 296/Pdt.G/2020/PA.GM.

Wawancara (interview) merupakan percakapan dengan maksud tertentu. Interview atau wawancara dilakukan terhadap beberapa pihak sebagai subjek penelitian yang akan dijadikan sebagai sumber data dalam penelitian ini yaitu para hakim yang bertugas menangani dan memutus perkara Nomor : 296/Pdt.G/2020/PA.GM di Pengadilan Lombok Barat.

Penelitian ini menggunakan data triangulasi sumber dan teknik. Triangulasi sumber untuk menguji keabsahan data dilakukan dengan mengecek dan membandingkan data yang diperoleh dari satu informan dengan informan lain. Triangulasi teknik dilakukan dengan membandingkan data dari hasil wawancara dengan observasi dan dokumentasi. Hal ini bertujuan untuk mendapatkan data yang reliabel yang didasarkan pada fakta yang ada di lapangan.

Adapun tujuan dari diadakannya penelitian ini adalah untuk dapat memahami factor-faktor apakah yang mempengaruhi dan menjadi dasar pertimbangan hukum hakim Pengadilan Agama Lombok Barat dalam menjatuhkan putusan terkait perkara pembagian waris anak perempuan jika bersama sama dengan saudara ayah/pewaris dalam pembagian waris dari harta peninggalan pewaris, selain itu adalah bertujuan menganalisis implikasi atau sosial dan hukum dari putusan tersebut terhadap perkembangan kewarisan anak perempuan di Kabupaten Lombok Barat.

\section{PEMBAHASAN}

\section{A. Putusan Anak Perempuan Mahjub Saudara Pewaris \\ Terkait kewarisan anak perempuan} di Indonesia berlaku tiga sistem hukum kewarisan yaitu sistem kewarisan berdasarkan hukum perdata barat (BW), hukum adat, dan hukum Islam (Muhammad Burhan,, 2017). Didalam ketiga sistem hukum kewarisan tersebut, 
antara hukum kewarisan yang diatur dalam KUHPerdata (BW), hukum adat dan hukum Islam, memposisikan kedudukan dan porsi bagian ahli waris anak perempuan berbeda-beda.

Dalam KUHPerdata menentukan anak perempuan dengan anak laki-laki memiliki kesetaraan dalam kedudukan sebagai ahli waris dan memiliki hak serta bagian yang sama dalam menerima harta warisan. Dalam sistem kewarisan BW menempatkan anak perempuan sebagai ahli waris utama (golongan I) bersama dengan anak laki-laki dan janda/duda, sementara saudara pewaris (paman/bibi) bersama-sama dengan ayah/ibu ditempatkan sebagai ahli waris golongan II artinya anak perempuan dalam sistem kewarisan BW adalah menghijab saudara pewaris (paman/bibi) untuk menerima warisan pewaris.

Dalam hukum kewarisan adat, menentukan bagian dari ahli waris anak perempuan, didasarkan pada adat kebiasaan yang berlaku di masing-masing daerah atau suatu komunitas masyarakat adat berdasarkan pola kekerabatan yang dimiliki (Muhammad Burhan, 2017).

Di dalam sistem kekerabatan patrilinial yaitu menarik keturunan dari garis laki-laki menempatkan anak perempuan dibawah kaum laki-laki. Anak laki-laki sebagai ahli waris utama sedangkan anak perempuan sebagai ahli waris kedua dibawah laki-laki. Dari sinilah mulai muncul diskriminasi gender yang terselubung dalam hukum adat (Edo Hendrako 2015). Dalam sistem kekerabatan patrilinial menentukan anak perempuan tidak mendapatkan warisan sama sekali. Namun sebaliknya dalam sistem kekerabatan matrilinial menentukan anak perempuan sebagai ahli waris utama dan mendapatkan bagian yang lebih besar daripada anak laki-laki, sedangkan dalam sistem kekerabatan bilateral atau parental mendudukkan anak perempuan setara dengan anak laki-laki dalam pewarisan hanya saja porsi bagian anak laki-laki lebih besar dari anak perempuan. begitu juga halnya dengan keberadaan saudara pewaris ketika bersama-sama dengan anak perempuan dalam satu kewarisan, masingmasing hukum adat berbeda-beda, ada yang menentukan anak perempuan mahjub saudara pewaris dan ada pula yang memberikan bagian waris kepada saudara pewaris ketika bersama dengan anak perempuan dalam satu kewarisan.

Dalam ketentuan hukum kewarisan Islam yang terdapat dalam Kompilasi Hukum Islam menempatkan anak perempuan setara dengan anak laki-laki dalam menerima warisan akan tetapi porsi bagian anak perempuan lebih kecil dari bagian anak laki-laki. Demikian juga 
halnya di dalam ayat kewarisan AlQur'an, menentukan bagian seorang anak perempuan adalah $1 / 2$ (separoh ) dari bagian anak laki-laki dan menempatkan saudara ayah/pewaris memiliki hak yang sama dengan anak perempuan sebagai ahli waris dalam menerima warisan yang tinggalkan pewaris.

Selain dari ketentuan yang terdapat di dalam ketiga sistem hukum kewarisan tersebut diatas, ketentuan terkait kedudukan anak perempuan dalam pewarisan terdapat pula dalam yurisprudensi yang menentukan kedudukan anak perempuan mengalami perkembangan dan kemajuan yang cukup penting dalam suatu pewarisan dimana anak perempuan dapat menghijab saudara pewaris dalam menerima warisan pewaris, dan porsi bagian anak perempuan disamakan dengan bagian anak laki-laki serta anak perempuan yang non muslim yang menjadi janda dari suami muslim berhak memperolah warisan peninggalan dari suaminya yang muslim.

Terkait dengan pembaharauan hukum kewarisan yurisprudensi yang menyangkut anak perempuan mahjub saudara pewaris ditemukan dalam putusan Pengadilan Agama Lombok Barat dalam putusan perkara Nomor : 296/Pdt.G/2020/PA.GM tanggal 6 Nopember 2020.
Dalam putusan perkara Nomor : 296/Pdt.G/2020/PA.GM tersebut, memang bukan perkara yang khusus menyangkut antara anak perempuan yang langsung berlawanan dengan saudara pewaris (paman/bibi) sebagai pihak-pihak, akan tetapi perkara tersebut merupakan perkara permohonan penetapan keahliwarisan dan tuntutan pembagian waris yang dilakukan oleh anak-anak dan cucu pewaris atas harta peninggalan ayah dan ibu atau kakek dan nenek mereka sebagai pewaris.

Di dalam perkara Nomor : 296/Pdt.G/2020/PA.GM. terdapat 2 kelompok penetapan keahliwarisan yaitu kelompok pertama berupa penetapan keahliwarisan dari pewaris asal yaitu orang tua/kakek nenek penggugat dan terguagat yang bernama Haji Muslim dan istrinya Hajjah Jawahir dan kelompok kedua adalah penetapan keahliwarisan dari anakanak pewaris asal (Haji Muslim dan istrinya Hajjah Jawahir) yang telah meninggal dunia pada saat pembagian waris dilakukan.

Dalam penetapan keahliwarisan pada kelompok pertama hakim menetapkan anak-anak dan cucu-cucu dari pewaris asal (Haji Muslim dan istrinya Hajjah Jawahir) sebagai ahli waris dari Haji Muslim dan istrinya Hajjah Jawahir yang berhak menerima warisan. Sedangkan dalam penetapan keahliwarisan 
pada kelompok kedua, hakim menetapkan ahli waris dari anak-anak pewaris asal (Haji Muslim dan istrinya Hajjah Jawahir) yang telah meninggal dunia pada saat pembagian waris dilakukan seperti misalnya penetapan ahli waris dari anak pewaris asal (Haji Muslim) bernama Rumini alias Inak Rumik yang telah meninggal dunia pada saat pembagian waris dilakukan dimana Rumini alias Inak Rumik pada saat meninggal dunia meninggalkan seorang anak perempuan dan 2 orang saudara seayah yang masih hidup bernama Hajjah Maemunah dan Hajjah Nurilah.

Di dalam penetapan keahliwarisan pada kelompok kedua, ditemukan bahwa anak pewaris asal (Haji Muslim) Rumini alias Inak Rumik meninggal dunia dengan memiliki seorang anak perempuan bernama Nurmini dan 2 orang saudara seayah bernama Hajjah Maemunah dan Hajjah Nurilah. Namun Hakim Pengadilan Agama Lombok Barat dalam putusannya hanya menetapkan Nurmini (anak perempuan) sebagai satu-satunya ahli waris dari Rumini alias Inak Rumik dan saudaranya yang seayah yang masih hidup (Hajjah Maemunah dan Hajjah Nurilah) dianggap bukan sebagai ahli waris dari Rumini alias Inak Rumik.

Selanjutnya Hakim Pengadilan Agama Lombok Barat dalam perkara
296/Pdt.G/2020/PA.GM menetapkan harta warisan Rumini alias Inak Rumik yang diperolehnya dari ayahnya pewaris asal (Haji Muslim) seluruhnya diwariskan kepada anak perempuannya Nurmini sebagai ashabah dan tidak dibagikan kepada Hajjah Maemunah dan Hajjah Nurilah sebagai saudara seayah karena Hajjah Maemunah dan Hajjah Nurilah terhijab oleh Nurmini, anak perempuan.

\section{B. Faktor-Faktor yang Mempengaruhi Pertimbangan Hakim di dalam Putusan}

Faktor-Faktor yang mempengaruhi pertimbangan hakim Pengadilan Agama Lombok Barat dalam memutuskan tidak memberikan bagian waris kepada saudara pewaris karena terhijab ahli waris anak perempuan sebagaimana dalam putusan perkara Nomor : 296/Pdt.G/2020/PA.GM adalah sebagai berikut :

\section{Faktor Rasa Keadilan}

Dalam salah satu amar putusan perkara tersebut, Hakim Pengadilan Agama Lombok Barat menetapkan keahliwarisan dari Rumini alias Inak Rumik adalah seorang anak perempuan bernama Nurmini. Sementara untuk saudaranya yang lain baik yang masih hidup seperti Hajjah Maemunah dan Hajjah Nurilah maupun yang sudah 
meninggal dunia tidak ditetapkan sebagai ahli waris Rumini alias Inak Rumik.

Dengan demikian dalam penetapan pembagian waris dari harta peninggalan Rumini alias Inak Rumik yang diperolehnya dari hasil pembagian waris harta peninggalan ayahnya (Haji Muslim), seluruhnya dibagikan atau diberikan hanya kepada anak perempuannya saja yang bernama Nurmini dan tidak dibagi atau diberikan kepada ahli waris lainnya seperti Hajjah Maemunah dan Hajjah Nurilah sebagai saudara lain ibu dari Rumini alias Inak Rumik yang masih hidup.

Hubungan kekerabatan atau persaudaraan antara Rumini alias Inak Rumik dengan Hajjah Maemunah dan Hajjah Nurilah berasal dari 1 (satu) ayah bernama Haji Muslim bin Haji Hapid dengan ibu yang berbeda yaitu Rumini alias Inak Rumik memiliki ibu bernama Inak Tahir (istri pertama Haji Muslim) dengan 3 (tiga) orang saudara yang telah meninggal dunia yaitu Munirin, Tajeri dan Haji Moh Rifa'i sedangkan Hajjah Maemunah dan Hajjah Nurilah memiliki ibu bernama Hajjah Jawahir (istri kedua Haji Muslim) bersama dengan seorang saudara lainnya bernama Haji Muhammad Mursid yang juga telah meninggal dunia.

Pertimbangan hukum yang dijadikan dasar di dalam memutuskan pembagian waris tersebut diatas adalah "demi rasa keadilan." Hakim Pengadilan Agama Giri Menang yang memeriksa perkara tersebut memang tidak memaparkan secara jelas dan tegas pertimbangan sebagaimana tersebut diatas, akan tetapi pertimbangan tersebut diketahui dari keterangan salah seorang hakim anggota yang menangani dan memutus perkara tersebut yaitu Hakim Fatihatur Rohmatis Silmi yang menyatakan hakim memutus tidak memberikan bagian waris kepada saudara Rumini alias Inak Rumik yaitu Hajjah Maemunah dan Hajjah Nurilah adalah dengan pertimbngan rasa keadilan. Jika bagian waris dari Rumini alias Inak Rumik dibagi juga kepada saudara, Hajjah Maemunah dan Hajjah Nurilah, maka Hajjah Maemunah dan Hajjah Nurilah akan mendapatkan bagian jauh lebih banyak dibandingkan bagian Nurmini anak perempuan dari Rumini alias Inak Rumik. Karena selain mendapatkan bagian warisan yang diperoleh dari harta peningglan ayahnya (Haji Muslim bin Haji Hapid) bersama-sama dengan Rumini alias Inak Rumik, Hajjah Maemunah dan Hajjah Nurilah juga memperoleh bagian lainnya dari harta peninggalan ibunya (Hajjah Jawahir) yang merupakan hasil pembagian harta bersama/gono-gini dengan suaminya Haji Muslim. Sehingga dengan demikian sangat tidak adil jika 
Nurmini (anak perempuan) yang hnaya mendapatkan bagian kecil dari bagian ibunya Rumini alias Inak Rumik tersebut akan dibagi lagi dengan Hajjah Maemunah dan Hajjah Nurilah (saudara) yang sudah memperoleh bagian lebih banyak yang diperoleh dari bagian ayahnya (Haji Muslim) dan juga ibunya, Hajjah Jawahir. (Fatihatur Rohmatis Silmi, wawancara, Giri Menang, 03 Mei 2021).

Pertimbangan rasa keadilan ini sesuai dengan tujuan hukum itu sendiri, dimana didalam literatur ilmu hukum terdapat 2 teori tentang tujuan hukum yaitu teori Utilities dan teori Etis. Tujuan hukum menurut teori Utilitis adalah untuk memberikan manfaat atau faedah bagi setiap orang dalam masyarakat. Sedangkan menurut teori Etis adalah menyandarkan tujuan hukum itu pada etika dan isi hukum itu ditentukan berdasarkan keyakinan tentang mana yang adil dan tidak adil. Tujuan hukum menurut teori Etis adalah semata-mata untuk mencapai atau menciptakan rasa keadilan dengan memberikan hak kepada setiap orang yang memang memiliki hak.

\section{Faktor Yurisprudensi}

Selain pertimbangan rasa keadilan sebagimana dipaparkan diatas, faktor lainnya yang dijadikan pertimbangan di dalam menetapkan pembagian waris dari harta peninggalan Rumini alias Inak
Rumik yang hanya diberikan atau dibagikan kepada anak perempuannya Nurmini dan tidak dibagi kepada saudara lain ibunya yang masih hidup yaitu Hajjah Maemunah dan Hajjah Nurilah adalah karena faktor mengikuti yurisprudensi (putusan MA RI, No. 86 K/AG/1994).

Di dalam pertimbngan hukumnya, memang Hakim Pengadilan Agama Giri Menang tidak secara tegas dan lugas menyebut alasan yurisprudensi, akan tetapi prinsip-prinsip pembaharuan hukum yang terdapat di dalam yurisprudensi tersebut diakomudir sebagai pertimbangan hukumnya seperti misalnya prinsip ketika terdapat ahli waris anak perempuan dalam suatu kewarisan, maka saudara pewaris tidak dianggap sebagai ahli waris dan oleh karenanya tidak diberikan hak bagian atas harta peninggalan pewaris.

Di dalam pertimbangan hukum Putusan perkara Nomor: 296/Pdt.G/2020/PA.GM, Hakim Pengadilan Agama Giri Menang menyatakan bahwa berdasarkan fakta Rumini meninggal pada tahun 2008 sedangkan suaminya bernama Sami'in telah lebih dahulu meninggal pada tahun 1992 dan hanya meninggalkan 1 orang anak bernama Nurmini selain itu karena tidak adanya ahli waris Dzawil Furud, maka anak perempuan mendapat ashobah 
atas seluruh harta waris dari Rumini alias Inak Rumik.

Dengan dinyatakannya tidak ada ahli waris Dzawil Furud, maka Hakim Pengadilan Agama Giri Menang tidak mengganggap Hajjah Maemunah dan Hajjah Nurilah (saudara pewaris Rumini alias Inak Rumik) sebagai ahli waris Dzawil Furud karena terdinding atau mahjub oleh anak perempuan dari Rumini alias Inak Rumik yang bernama Nurmini.

Hal ini sesuai dengan hasil wawancara penulis dengan hakim yang kebetulan menjadi ketua majelis dalam perkara tersebut diatas yaitu Hakim Unung Sulistio Hadi dengan menyatakan bahwa tidak diberikannya bagian waris kepada saudara pewaris Rumini alias Inak Rumik yang masih hidup bernama Hajjah Maemunah dan Hajjah Jawahir karena selain karena pertimbangan rasa keadilan juga karena Majelis mempertimbangkan keberadaan yurisprudensi (putusan Mahkamah Agung Nomor: 86 K/AG/1995) dalam menetapkan pembagian harta peninggalan Rumini alias Inak Rumik yang seluruhnya jatuh kepada anak perempuannya Nurmini. (Unung Sulistio Hadi, wawncara, Praya, 20 Mei 2021)

Hakim Pengadilan Agama Lombok Barat dalam hal ini telah menjatuhkan putusan yang mengandung pembaharuan hukum mengikuti yurisprudensi, meskipun di dalam pewrtimbngan hukumnya tidak menguraikan secara tegas dan jelas terkait mengikuti yurisprudensi tersebut.

\section{Implikasi Putusan terhadap Perkembangan Kewarisan Anak Perempuan di Kabupaten Lombok Barat.}

\section{Implikasi Sosial}

Putusan Hakim Pengadilan Agama Giri Menang yang memutuskan tidak memberikan bagian waris kepada saudara pewaris karena terhijab oleh ahli waris anak perempuan memiliki implikasi sosial sebagai berikut :

\section{a.) Teruwujudnya rasa keadilan bagi anak perempuan}

Bahwa untuk Putusan Pengadilan Agama Giri Menang yang mendudukkan anak perempuan sebagai penghijab saudara pewaris (paman/bibi) dalam menerima warisan pewaris telah memberikan angin segar bagi perkembangan kewarisan anak perempuan di Kabupaten Lombok Barat. Putusan tersebut memiliki efek soaial dan ekonomis yang cukup besar terhadap ahli waris anak perempuan. Rasa ketidak adilan yang selama ini dirasakaan dan membebani anak perempuan, dimana setiap harta warisan yang ditinggalkan oleh orang tuanya/pewaris, maka anak 
perempuan akan berbagi dengan paman/bibinya (saudara pewaris) yang notabene memiliki hubungan kekerabatan yang lebih jauh dengan pewaris dibandingkan dengan anak perempuan.

Anak perempuan memiliki hubungan nasab ke bawah satu tingkat dengan ayah/ibunya (pewaris) sementara paman/bibi memiliki hubungan kekerabatan menyamping dengan pewaris (saudaranya). Ketika warisan terbuka, anak perempuan akan mendapatkan 1/2 jikia dia seorang dan mendapatkan 2/3 jika mereka dua orang atau lebih dan sisanya akan di terima oleh paman/bibi sebagai saudara pewaris.

Hal inilah yang dirasakan tidak adil oleh anak perempuan, karena harta warisan akan dibagi dengan orang yang tidak termasuk dalam kelaurga inti dari kelaurga anak perempauan itu. Paman/bibi memiliki keluarga inti sendiri yaitu anakanak dan istrinya. Rasa ketidak adilan itu akan sangat terasa ketika pewaris dalam kondisi atau keadaan sakit, dimana yang lebih memiliki kewajiban dan tanggung jawab untuk mengurus pewaris tentunya keluarga inti yaitu anak dan istri pewaris sendiri sementara paman/bibi tidak memiliki kewajiban utama untuk mengurus pewaris (saudaranya) karena paman/bibi memiliki kewajiban dan tanggung jawab sendiri untuk mengurus kelurganya (anak dan isterinya).

Selain itu tidak jarang ditemukan kasus bahwa saudara pewaris (paman/bibi) tidak mau mengurus anak-anak perempuan pewaris ketika pewaris telah meninggal dunia karena saudara pewaris (paman/bibi) akan disibukkan mengurus keluarganya sendiri. Sangat banyak kasus ditemukan ketika saudara pewaris (paman/bibi) setelah membagi dan mendapatkan harta warisan pewaris, tidak peduli lagi bahkan menelantarkan dan tidak mau mengurus anak perempuan dari pewaris. Keadaankeadaan seperti inilah yang dirasakan sebagai ke tidak adilan jika warta warisan pewaris dibagi kepada saudara pewaris (paman/bibi).

Dengan adanya putusan Pengadilan Agama Giri Menang tersebut, maka rasa ketidak adilan bagi anak perempuan yang telah melekat begitu lama telah terlepas dan sudah tidak dieasakan lagi oleh anak perempuan.

\section{b.) Anak perempuan merasa dihargai, tidak lagi dipandang sebelah mata oleh paman/bibi}

Dampak sosial lainnya dari putusan tersebut adalah bahwa anak perempuan merasa dihargai, tidak lagi dipandang sebelah mata oleh paman/bibi. Anggapan anak perempuan sebagai mahluk yang tidak begitu bernilai dan tidak 
diperhitungkan sama sekali dimata masyarakat sebagai akibat dari pengaruh kultur budaya bangsa Arab yang tidak pernah memberikan hak apapun kepada anak perempuan termasuk hak untuk hidup dengan layak menjadi sirna dan sebaliknya perempuan sudah mulai mendapat tempat untuk dihargai, dihormati dan ditegakkan hak-hak hukumnya dalam segala hal termasuk dalam hal kewarisan.

Dengan adanya putusan Pengadilan tersebut, tidak lagi kita temukan di dalam kehidupan sehari-hari seorang paman/bibi memguasai harta warisan dari saudaranya dengan dalih anak perempuan dari pewaris masih kecil dan belum dewasa sehingga paman/bibilah sementara yang memegang dan menguasai harta warisan pewaris. Namun ketika si anak perempuan sudah dewasa, sang paman/bibi memberikan harta warisan tersebut kepada anak peerempuan yang sudah dewasa tadi hanya sebagian kecil saja dari harta warisan tersebut dengan alasan bahwa paman/bibi juga memiliki hak yang sama mewarisi harta peninggalan saudaranya (pewaris).

Bahkan terdapat kasus bahwa paman/bibi sama sekali tidak mau memberikan bagian kepada anak perempuan pewaris karena anak perempuan pewaris tidak mengerti tentang warisan dan anak perempuan tersebut lemah dan buta huruf sehingga takut melawan atau meminta warisan tersebut kepada paman/bibinya.

Dengan keadaan ahli waris anak perempuan seperti itu maka paman/bibi leluasa menguasai dan menikmati harta peninggalan pewaris bahkan penguasaan itu berlangsung cukup lama sejak meninggalnya pewaris atau sejak kecilnya anak perempuan pewaris.

Dengan adanya putusan Pengadilan Agama Lombok Barat yang memutuskan tidak memberikan hak dan bagian waris kepada paman/bibi, maka telah memperjelas posisi paman/bibi terhadap harta waris tersebut sehingga setidak-tidaknya akan berdampak terhadap penilaian masyarakat terhadap penguasaan yang dilakukan oleh paman/bibi terhadap harta warisan anak perempuan.

Paman/bibi yang menguasai dan menikmati harta warisan saudaranya dan tidak memberikannya kepada anak perempuan selaku yang berhak mewarisi harta waris tersebut, naka paman/bibi akan mendapatkan sanksi sosial berupa paman/bibi akan dicemooh dan dipandang rendah dan hina serta tidak memiliki harga diri di tangah-tengah masyarakat. 


\section{c.) Bertambahnya Nilai Ekonomis bagi}

\section{Anak Perempuan.}

Dengan tidak terbaginya harta warisan kepada saudara pewaris, maka tentunya akan memberikan nilai ekonomi yang lebih bagi anak perempuan karena anak perempuan menjadi ashabah atau satu-satunya ahli waris yang akan mendapatkan dan menikmati harta yang ditinggalkan pewaris.

Dikatakan memiliki nilai ekonomis yang lebih yaitu jika harta warisan yang kebanyakan adalah berupa tanah kebun dan sawah, jika tanah kebun dan sawah tersebut utuh dan tidak terbagi, maka jelas hasil panennya akan lebih banyak diperoleh oleh ahli waris anak perempuan dan akan berkurang hasil paenennya jika tanah kebun dan sawah itu terbagi dengan saudara pewaris (paman/bibi).

Demikian pula halnya anak perempuan yang ditinggal pewaris, memiliki anak (cucu pewaris) dimana cucu pewaris tersebut seorang yatim, ayahnya telah meninggal dunia sehingga hanya diurus oleh ibunya (anak perempuan pewaris), maka apabila harta warisan pewaris dibagi dan diberikan juga kepada saudara (paman/bibi), pembagian itu berdampak pada berkurangnya nilai materi dari harta warisan tersebut dan secara ekonomi akan mengurangi perolehan anak perempuan atas materi harta warisan tersebut namun apabila harta warisan tidak dibagi kepada saudara (paman/bibi), maka tentunya harta warisan tersebut utuh dapat dimanfaatkan oleh anak perempuan untuk membiayi hidupnya dan untuk menghidupi, membesarkan serta memberikan pendidikan yang layak bagi anaknya (cucu pewaris) tersebut.

\section{Implikasi Hukum}

Putusan Pengadilan Agama Lombok Barat yang memutuskan tidak memberikan bagian waris kepada paman/bibi karena terhalang atau mahjub oleh ahli waris anak perempuan memiliki dampak atau implikasi hukum sebagai berikut :

\section{Anak perempuan memiliki jaminan}

hukum tidak terbaginya harta peninggalan orang tuanya dengan paman/bibi.

Dengan adanya putusan Pengadilan Agama Giri Menang yang mengandung pembaharuan hukum mengikuti yurisprudensi, yang memutuskan tidak memberikan bagian waris kepada paman/bibi jika terdapat ahli waris anak perempuan tentunya dapat dijadikan pondasi yang melahirkan landasan hukum yang kuat atas jaminan bahwa harta warisan hanya akan dibagi dan didapatkan oleh anak perempuan saja sebagai ashabah tanpa harus dibagi dan diberikan kepada saudara pewaris (paman/bibi) jika 
memang saudara pewaris bersama-sama dengan anak perempuan dalam suatu kewarisan.

Putusan ini haruslah diikuti dan dipatuhi oleh semua pihak yang terkait dalam sengketa kewarisan tersebut. Jika salah satu pihak yang menguasai obyek harta warisan dan merasa tidak puas dan tidak menerima putusan tersebut kemudian tidak mau mematuhi dan melaksanakan isi amar dari putusan, maka pihak yang tidak mematuhi dan tidak mau melaksanakan putusan telah melakukan suatu pelanggaran hukum dan dapat diancam dengan tindak pidana "melawan putusan pengadilan atau tindak pidana lainnya" sebagaimana diataur dalam KUHP.

Putusan ini memiliki implikasi hukum bagi perkembangan kewarisan perempuan di Kabupten Lombok Barat dimana anak perempuan telah mendapatkan jaminan bahwa hakhaknya atas harta peninggalan orang tuanya tidak lagi dapat dibagi-bagi kepada pamam/bibi jika bersama-sama dalam satu kewarisan. Sehingga dengan putusan tersebut anak perempuan menjadi ahli waris satu-satunya diluar janda/duda, ayah/ibu yang menerima seluruh bagian dari harta peninggalan orangtuanya yang telah meninggal dunia, menjadi ashabah tanpa dibagi-bagi dengan paman/bibi.
2. Adanya kepastian hukum bagi anak perempuan sebagai penghijab paman/bibi untuk mendapatkan harta warisan pewaris.

Dengan terbitnya putusan Pengadilan Agama Lombok Barat Nomor : 296/Pdt.G/2019/PA.GM, tanggal 10 Nopember 2020 tersebut diatas, anak perempuan mendapatkan suatu kepastian hukum bahwa ia sebagai pendinding atau penghalang saudara pewaris menjadi ahli waris di dalam suatu pewarisan. Jika nantinya di Pengadilan Agama Lombok Barat terdapat kasus serupa anak perempuan bersama dengan saudara pewaris dalam suatu pewarisan, maka putusan Nomor : 296/Pdt.G/2019/PA.GM tersebut dapat diacu oleh hakim-hakim lainnya untuk menetapkan saudara pewaris bukanlah sebagai ahli waris dan tidak memberikan bagian kepada saudara pewaris (paman/bibi) jika terdapat ahli waris anak perempuan.

\section{Adanya kemajuan hukum terhadap} perkembangan kewarisan anak perempuan di Kabupaten Lombok

\section{Barat.}

Putusan yang mendudukkan anak perempuan mahjub saudara pewaris merupakan kemajuan dalam perkembangan kewarisan anak perempuan di Kabupaten Lombok Barat karena banyak juga Pengadilan Agama di daerah 
lain yang tidak memberikan putusan yang mendudukkan anak perempuan sebagai hijab saudara pewaris sehingga harta warisan akan terbagi dengan paman/bibi jika bersama-sama dengan anak perempuan dalam suatu kewarisan.

Bahwa kasus pembagian waris antara anak perempuan dengan saudara pewaris di Pengadilan Agama Lombok Barat sangat minim sekali jumlahnya yaitu hanya 2 putusan saja. Dan diantara 2 putusan tersebut, 1 putusan yang memutuskan tidak memberikan bagian waris kepada saudara pewaris karena terhijab oleh anak perempuan, dan 1 putusan lagi memutuskan ada anak perempuan yang mahjub saudara pewaris dan ada juga anak perempuan tidak mahjub saudara pewaris.

Dari penjelasan tersebut diatas, sudah jelas sekali bahwa kedua putusan tersebut merupakan tonggak kemajuan yang cukup berarti bagi perkembangan keahliwarisan anak perempuan di Kabupaten Lombok Barat.

\section{Meningkatnya Pengajuan Upaya Hukum oleh Pihak Paman/Bibi karena Tidak Puas dengan Putusan Pembaguan Waris yang Telah Diputuskan.}

Putusan Pengadilan Agama Giri Menang yang memutus perkara kewarisan dengan tidak memberikan bagian waris untuk paman/bibi karena terhijab anak perempuan berimplikasi pula pada meningkatnya volume pengajuan upaya hukum baik upaya hukum banding ataupun kasasi yang dilakukan oleh pihak-pihak yang tidak puas atas putusan tersebut.

Di dalam ketentuan hukum acara kewarisan para pihak yang bersengketa diberikan dua hak untuk menyikapi Putusan yang dijatuhkan pengadilan tingkat pertama yaitu "menrima putusan" atau "menolak putusan." Terhadap putusan pembagian waris yang tidak memberikan bagian kepada paman/bibi karena terhijab anak perempuan dapat dilakukan penolakan oleh paman/bibi jika putusan tersebut dinilai tidak berpihak dan tidak adil. Penolakan atas putusan Pengadilan Agama tingkat pertama tersebut dapat dilakukan dengan mengajukan upaya hukum berupa permohonan banding ke Pengadilan Tinggi Agama yang kemudian dapat dilanjutkan dengan mengajukan kasasi ke Mahkamah Agung.

\section{KESIMPULAN}

Dari paparan hasil dan pembahasan penelitian sebagaiman diuraikan diatas, maka dapat ditarik kesimpulan sebagai berikut:

- Faktor-Faktor yang mempengaruhi 
pertimbangan hukum hakim

bagi anak perempuan sebagai

Pengadilan Agama Lombok Barat penghijab paman/bibi untuk dalam memutuskan anak perempuan mahjub saudara pewaris (paman/bibi) tidak memberikan bagian waris kepada saudara pewaris (paman/bibi) adalah faktor rasa keadilan dan yurisprudensi. Meskipun faktorfaktor ini tidak diuraikan secara jelas dan tegas dalam pertimbangan hukum putusan akan tetapi pertimbanganpertimbangan tersebut terkuak dari hasil wawncara peneliti dengan hakim-hakim yang menangani dan memutus perkara tersebut.

- Implikasi sosial dari putusan yang tidak memberikan bagian waris kepada saudara pewaris karena terhalang oleh anak perempuan adalah teruwujudnya rasa keadilan bagi anak perempuan, anak perempuan merasa dihargai, tidak lagi dipandang sebelah mata dan adanya sanksi sosial bagi paman/bibi) dan bertambahnya nilai ekonomis bagi Anak Perempuan jika harta warisan tidak dibagi dengan paman/bibi.Selanjutnya implikasi hukum atas putusan tidak terbaginya harta warisan kepada saudara pewaris yaitu anak perempuan memiliki jaminan hukum harta peninggalan orang tuanya tidak dibagi dengan paman/bibi, Adanya kepastian hukum

mendapatkan harta warisan pewaris dan terciptanya kemajuan hukum terhadap perkembangan kewarisan anak perempuan di Kabupaten Lombok Barat

\section{SARAN}

Dengan demikian disarankan untuk kedepannya agar Pengadilan Agama Lombok Barat lebih berani dan intensif untuk menjatuhkan putusan pembaharuan yang mendudukkan anak perempuan sebagai mahjub saudara pewaris. Disamping itu juga diharapkan agar Pengadilan Agama Lombok Barat berani menjatuhkan putusan-putusan pembaharuan lainnya seperti putusan yang memberikan bagian yang sama rata antara anak laki-laki dengan anak perempuan dan memberikan bagian waris terhadap istri muslim atas harta peninggalan suaminya yang muslim demi kemajuan dan pengembangan hukum kewarisan anak perempuan di Kabupaten Lombok Barat.

\section{DAFTAR RUJUKAN}

Alkostar, A. M Sholeh Amin. (1986). Pembangunan Hukum dalam Perspektif Politik Hukum Nasional. RAJAWALI PERS.

Amron, M. (2016). Kedudukan Ahli Waris Anak Perempuan bersama Ahli Waris 
Saudara dalam Hukum Waris Islam di Pengadilan Agama Semarang" (Tesis, Program Pasca Sarjana Magister Kenotariatan Uninersitas Diponegoro, Semarang).

Anwar A dan Syamsul Bahri. (2017). JIM BIDANG

HUKUM

KEPERDATAAN, November 2017, Volume 1, Nomor 2, Studi Kasus Putusan Nomor 92/Pdt.G/2009/Pa$M d n$ Tentang Pembagian Warisan Sama Rata Anak Laki-Laki Dan Anak Perempuan, http://www. jim. Unsyiah .ac.id/perdata/article/view/13065

Burhan, M. (2017). JURNAL MAHKAMAH, Desember 2017, Volume 2, Nonor 2. Kedudukan dan hak perempuan sebagai Ahli waris dalam hukum kewarisan indonesia (tinjauan hukum perdata, adat dan islam), $\quad 284, \quad$ http://dx. DOI.org/10.25217/jm.v2i2.14.

Cahyani, A.I. (2016). AD-DAULLAH, Desember 2016, Volume 5, Nomor 2. Pembaharuan Hukum dalam Kompilasi Hukum Islam, 320, DOI: https://doi.org/10.24252/ad.v5i2 .4850

Erlyta, T.A. (2019). JURNAL ILMIAH FAKULTAS HUKUM UNIVERSITAS MATARAM, Juli 2019, Analisis Terhadap Putusan Pengadilan Agama Praya Nomor 0038/Pdt.G/2018/Pa.Pra tentang Pembagian Warisan Terhadap Ahli Waris Perempuan, https://fh.unram.ac.id/wpcontent/uploads/2019/

Hendrako, E. (2015). LEX PRIVATUM, Januari-Maret 2015, Volume III, Nomor 1. Hak Waris Anak Perempuan Terhadap Harta
Peninggalan (Studi Kasus Putusan MA RI No.4766/Pdt/1998), 85, https://ejournal.unsrat.ac.id/index.php /lexprivatum/article/ view /7028/6538

Herdiansyah, H. (2010). Metode Penelitian Kualtatif Untuk Ilmu-Ilmu Sosial. SALEMBA HUMANIKA.

Jatnika, R. (1996). Jalan Mencari Hukum Islam Upaya ke Arah Pemahaman metodologi Ijtihad, dalam Amrullah, Ahmad SF. Dimensi Hukum Islam dalam Sistem hukum Nasional, Cet. I. GEMA INSANI PRESS.

Moleong, J. L. (2005). Metodologi Penelitian Kualitatif. PT. REMAJA ROSDAKARYA.

Nasution, S. (2004). Metode Research (Penelitian Ilmiah). BUMI AKSARA.

Pasamai, S. (2013). Sosiologi dan Sosiologi Hukum. ARUS TIMUR.

Putra, M. (2018). JURNAL MORALITY, Juni 2018, Volume 4, Nomor 1, Hukum dan perubahan sosial (tinjauan terhadap modernisasi dari aspek kemajuan teknologi), 49. http://jurnal.upgriplk.ac.id/index.php/ morality/article/view/66
Rahardjo, S. (1986). Hukum dan masyarakat. BANDUNG.

Rochmad. (2017). HUKUM KHAIRA UMMAH, Desember 2017, Volume 12. Nomor 4 Pembagian Harta Waris Antara Anak Laki-Laki Dan Anak Perempuan: Studi Putusan Pengadilan Agama Semarang Nomor: 1545/PDT.G/2010/PA.SM, http://lppmunissula. com/ jurnal. unissula.ac.id/index.php/jhku/article/v iew/2296 
Saragih, E. E. Mustamam, Mukidi. (2019), JOURNAL OF EDUCATION, HUMANIORA AND SOCIAL SCIENCES, Desember 2019, Volume 2, Nomor 2, Kedudukan Anak Perempuan dalam Pembagian Harta Warisan menurut Hukum Islam (Studi Kasus Putusan Pengadilan Agama Medan No. 40/Pdt.G/2017/PA.Mdn), https://doi.org/10.34007/jehss.v2i2.92

Soekanto, S. (2012). Pokok-Pokok Sosiologi Hukum. RAJAWALI PERS.

Sukanto, S. (2009). Sosiologi, Suatu Pengantar. RAJA GRAFINDO. 